\title{
Natura ludzka: założenie i nadzieja antropologii
}

Nigel Rapport

TEKSTY DRUGIE 2018, NR 1, S. 201-221

DOI: $10.18318 /$ td.2018.1.11

Wszyscy jesteśmy ludźmi i powinniśmy traktować się uczciwie i z szacunkiem. Nie bierzmy poważnie bardziej szczegółowych klasyfikacji. Czy w ogóle między świadomymi dorosłymi ludźmi powinno się pozwalać na kategoryzacje?

Ernest Gellner

\section{Wstęp}

Problem natury ludzkiej, problem tego, co to znaczy być człowiekiem, był centralną kwestią nauki „antropologicznej" przynajmniej od chwili, kiedy Kant ${ }^{2}$ przedstawił pod koniec XVIII wieku pierwsze nowożytne sformułowanie tej dyscypliny. Jednocześnie pojawiają się opinie,

1 E. Gellner The mightier pen? Edward Said and the double standards of inside-out colonialism, "Times Literary Supplement" 1993 No. 4690, S. $3-4$.

2 I. Kant Antropologia w ujęciu pragmatycznym, przeł. E. Drzazgowska, P. Sosnowska, IFiS PAN, Warszawa 2005.

\section{Nigel Rapport -}

profesor studiów antropologicznych i filozoficznych na Uniwersytecie w St. Andrews. Jego zainteresowania badawcze to teoria społeczna, fenomenologia, tożsamość, antropologia literatury, teoria studiów kosmopolitycznych, liberalizm, symboliczny interakcjonizm. Autor książek: Anyone, Cosmopolitan Subject of Anthropology (2012); Distortion and Love: An anthropological reading of the art and life of Stanley Spencer (2016). 
że antropologia igra tutaj z pojęciem, które zostało już tak skompromitowane, że nie da się go odratować. Kompromitacja ta ma polegać na tym, że pojęcie „natury ludzkiej” było historycznie interpretowane esencjalistycznie, hierarchicznie i wykluczająco, miało swój udział w podtrzymywaniu władzy mężczyzny nad kobietą, dorosłego nad dzieckiem, rozwiniętego nad prymitywnym, zachodniego nad wschodnim, racjonalnego nad emocjonalnym i świadomego nad spontanicznym. W niniejszym tekście chcę jednak pokazać, że „natura ludzka” to przestrzeń, w którą antropologia może mieć swój specjalny wkład. W tym sensie, jak to ujmuje Donna Haraway ${ }^{3}$, ,odkrywanie i odkrywanie na nowo natury jest bodaj najważniejszym obszarem, na którym w naszych czasach uwidaczniają się nadzieje, przemoc i opór mieszkańców Planety Ziemia”. Pojęcie "natury ludzkiej” jest powszechne i pojemne, a sięgają po nie bez najmniejszych skrupułów przedstawiciele zarazem radykalnej krytyki, jak i najtwardszej reakcji. Z tego też powodu jest ono dla antropologii wciąż tematem aktualnym i interesującym, żeby nie powiedzieć koniecznym, który antropologia powinna nie tylko objaśniać, ale według mnie również zrehabilitować. Pojęcie „natury ludzkiej” jest niezbędnym punktem węzłowym dyscypliny, w której „[o]pisanie człowieka” (writing of a human) może objąć również wymiar etyczny i estetyczny, a nie tylko naukowy.

\section{Unikalność człowieka}

W swoim oświeceniowym sformułowaniu Kant mówił o antropologii jako dyscyplinie, która jest zarazem ontologiczna, epistemologiczna i moralno- polityczna. Patrząc od strony naukowej, antropologia miała być tym sposobem budowania wiedzy o człowieku, który dawał nadzieję, że przekroczenie granic tego, co zwyczajowe, zdroworozsądkowe czy objawione jest celem zarazem możliwym do osiągnięcia, jak i etycznie słusznym. Patrząc od strony etycznej, antropologia ucieleśniała sprzeciw wobec ideologii ancien régime’u, która podkreślała istotowe różnice w naturze i wartości między patrycjuszem a plebejuszem, między mężczyzną a kobietą, między Francuzem a Niemcem, między chrześcijaninem a żydem. Zamiast tego antropologia miała proponować obietnicę „kosmopolitycznego” pokoju i wspólnoty całej ludzkości.

Johann Herder, uczeń Kanta, wystąpił przeciwko tym pomysłom z pozycji „romantycznych”: uważał, że nie da się pojąć takiej rzeczy jak „ludzkość”,

3 D. Haraway Modest_Witness@Second_Millenium.FemaleMan_Meets_Oncomouse, Routledge, London 1997, s. 1. 
a tylko Niemców, Francuzów itd.: a więc ludzi różnorako wrośniętych we wspólnoty krwi i ziemi. Według George’a Stockinga ${ }^{4}$ antropologia w całej swojej nowożytnej historii jest dialektycznie rozdarta między uniwersalizmem anthropos i różnorodnością ethnos, czyli między Kantem a Herderem. Chodziło o to, czy ludzie mają być postrzegani jako tacy sami przez to, że zamieszkują różne kultury i światy, czy właśnie mimo tych różnic? Czy stają się ludźmi w ramach określonej kultury, czy też ich człowieczeństwo (świadomość, zdolności twórcze, indywidualność, godność) przekraczają specyfikę poszczególnych kultur? W sformułowaniu Clifforda Geertza ${ }^{5}$ to jest pytanie o to, jak antropologia łączy biologiczną jedność całej ludzkości i ogólnoludzką racjonalność z „ogromną naturalną różnorodnością form kulturowych"?

Ernest Gellner swoim zwyczajem przyjął w tej sprawie zdecydowane stanowisko. Według niego jest błędem kategorialnym mieszać tę „ogromną naturalną różnorodność form kulturowych"6 $\mathrm{z}$ różnorodnością ludzkich natur. Według Gellnera nawet wśród „świadomych dorosłych", którzy się na to zgadzają, klasyfikowanie ludzi według zamkniętych domen społecznych lub kulturowych to praktyka mylna i niebezpieczna ${ }^{7}$, a relatywizm - poznawczy czy moralny - to dla niego tragiczny nonsens ${ }^{8}$. Formy kultury to wyraz rzeczywistości symbolicznej, a ludzka natura to rzeczywistość ontologiczna i naturalna. Natura człowieka nie daje się ukrócić tylko dlatego, że ludzie poddają się tej czy innej symbolicznej klasyfikacji tożsamości. Ludzie nie stają się naprawdę różni od siebie tylko dlatego, że określają siebie (albo ktoś ich określa) jako Niemców, a nie Żydów, sunnitów a nie szyitów, patrycjuszy a nie plebejuszy czy nawet jako męskich a nie kobiecych. Innymi słowy, nie wszystkie twierdzenia o różnicach między ludźmi mają wymiar prawdziwościowy. Niektóre z takich stwierdzeń, a w kontekście polityki tożsamości nawet większość, to tylko retoryka, kwestia estetyki, polityki, afektu, smaku, komfortu czy współzawodnictwa. Zamazywanie różnic między

4 G. Stocking The Ethnographer's Magic and Other Essays in the History of Anthropology, University of Wisconsin Press, Madison 1992, s. 347, 361.

5 C. Geertz Interpretacja Kultur. Wybrane Eseje, przeł. M.M. Piechaczek, Wydawnictwo UJ, Kraków 2005, s. 38.

6 Tamże.

7 E. Gellner The mightier pen? Edward Said and the double standards of inside-out colonialism, „Times Literary Supplement" 1993 No. 4690, s. 3.

8 E. Gellner Anything goes: The carnival of cheap relativism which threatens to swamp the coming fin de millenaire, "Times Literary Supplement” 1995 No. 4811, s. 8. 
sprawami retorycznymi lub symbolicznymi z jednej strony, a naturalnymi bądź ontologicznymi z drugiej to, jak stwierdził teoretyk polityki George Kateb ${ }^{9}$, ,groteska”. Życie społeczne staje się groteską, jeśli nurzając się w różnych ekspresjach naszej tożsamości kulturowej - kibiców Arsenalu lub Chelsea, smakoszów Coli lub Pepsi, wyznawców islamu lub chrześcijaństwa, miłośników muzyki klasycznej lub punk - nie potrafimy zarazem patrzeć na nie z należytą ironią. „Wszyscy jesteśmy ludźmi”, podsumowywał Gellner ${ }^{10}$, i nie powinniśmy brać „poważnie bardziej szczegółowych klasyfikacji”.

Wezwanie Gellnera, jeżeli chcemy je wziąć poważnie, oznacza radykalną rekalibrację celów antropologii. Oznacza odejście od relatywistycznej i kulturalistycznej ortodoksji, która dominowała od czasu, kiedy Herder przekazał pałeczkę myślicielom w rodzaju Durkheima, Maussa, Foucaulta czy Latoura. Jest naukowo właściwe i etycznie konieczne, by stwierdzić, że „to, co ludzkie", jest naczelnym, porządkującym obszarem badań antropologicznych. „To, co ludzkie”, trzeba powiedzieć, obejmuje złożona unikalność (complex singularity), którą można lepiej poznać, której los można poprawić i której samo istnienie jest warunkiem wspólnotowej (socjokulturowej) różnorodności. Można to rozumieć jako wezwanie do jawnie Kantowskiej lub „kosmopolitycznej" antropologii. Obejmuje to ontologiczny projekt zdefiniowania tego, co ludzkie, ludzkich możliwości i ułomności, jako uniwersaliów przekraczających różnice idiomów społecznych, kulturowych czy historycznych. Obejmuje też epistemologiczny projekt szukania dróg, którymi można by najlepiej zbadać to, co ludzkie, w jego poszczególnej, jednostkowej nieredukowalności, która najlepiej ujmie obiektywność subiektywnego. Obejmuje wreszcie moralno-polityczny projekt zabezpieczenia człowieka, wzmocnienia możliwości ekspresji indywidualnej, przekraczającej poszczególne okoliczności społeczne, kulturowe i historyczne. „Przedtekstowe” zrozumienie człowieka - w moim pojęciu - jest nieusuwalną częścią rozumienia ludzkiej rzeczywistości, która w wymiarze ontologicznym znacznie przekracza zaledwie kulturową ( $\mathrm{i}$,tekstową") konstrukcję świata relacji symbolicznych.

Dla Kanta antropologia łączyła się głęboko i nierozerwalnie z jego szerszą, kosmopolityczną wizją i była dla niej ważnym narzędziem. Antropologia miała wyjaśnić naturę tego, co w ludziach jest takie same. Miała to zrobić w taki sposób, żeby to, czym ludzie się różnią, nie wymazało tego, że należy

9 G. Kateb Democratic Individuality and the Claim of Politics, "Political Theory” 1984 No. 12 (3), s. 351. 
się im wszystkim równe traktowanie w sprawiedliwym społeczeństwie i że rzeczone sprawiedliwe społeczeństwo obejmie kiedyś wszystkich ludzi. W myśleniu Kanta „kosmopolityczne prawo” (ius cosmopoliticum) miało traktować wszystkich ludzi jako obywateli powszechnego, moralnego państwa ludzkości, gdzie gościnność i kulturowa ogłada byłyby tarczą, pod którą mógłby schronić się każdy i wszędzie. Wydaje mi się, że wizja Gellnera „wszyscy jesteśmy ludźmi” - jest równie kosmopolityczna. Wskazuje ona na głębokie powiązania między, z jednej strony, naszą „wszystkością” (allness), czyli zbiorem poszczególnych żywotów jednostkowych, ucieleśniających konkretne i precyzyjnie umiejscowione światy społeczne (czyli polis), a naszym człowieczeństwem (humanness), czyli ogólnogatunkową uniwersalnością i powszechnością (czyli kosmosem), z drugiej. Żadnych bardziej szczegółowych klasyfikacji nie należy brać poważnie. Narodowość, rasa, płeć, a także klasa, pochodzenie etniczne, religia, kasta, społeczność czy kultura - to są wszystko epifenomeny, symboliczne, dyskursywne i retoryczne konstrukty, których nie należy mylić z trwałą ontologiczną rzeczywistością ludzkiej kondycji, naszej humanitas i naszej indywidualności. Antropologia zajmuje się unikalnym zjawiskiem człowieczeństwa, które przejawia się w nieskończonej różnorodności żywotów indywidualnych. Ludzkość i indywidualność to te bieguny jednakowości i zróżnicowania, między którymi kosmopolityczny projekt antropologii poszukuje swojej prawdy.

\section{"Zygzakowanie" jako metodologia}

Ale jak konkretnie to zrobić? Jak ująć w pojęcia i jak zapisać te relacje między unikalnością i zróżnicowaniem? Według George’a Stockinga poruszaliśmy się jak dotąd cyklicznie od jednego do drugiego. Lub też twierdziliśmy ( $a$ la Geertz), że próba połączenia wspólnej dla wszystkich ludzkiej ogólności $\mathrm{z}$ różnorodnością kulturową to kwadratura koła. Chciałbym więc niniejszym przedstawić dwie koncepcje, z których pierwsza dotyczy sposobów pisania i reprezentacji, idących takim właśnie zygzakiem między jednakowością i zróżnicowaniem, a druga dotyczy epistemologii, rozróżniającej uniwersalne ludzkie możliwości (capacities) ${ }^{11}$ od ich konkretnych, jednostkowych ludzkich realizacji (substantiations). „Jeśli antropologia nie jest chimera, to niczym nie jest”, stwierdził kiedyś Ray Abrahams w czasie dyskusji o statusie antropologii

11 Wależności od kontekstu stosowany przez Rapporta termin capacity tłumaczymy jako „możliwość" lub „potencjał” [przyp. tłum.]. 
jako nauki generalizującej ${ }^{12}$.To sformułowanie dobrze oddaje nasz paradoks. Antropologia, powiadam, rozpościera się między jednakowością a zróżnicowaniem właśnie niczym chimera, jest hybrydą, jawi się jako wewnętrznie sprzeczna. Antropologia nalega zarazem na to, żeby oddać sprawiedliwość intensywności, idiosynkrazji i ulotności doświadczenia oraz żeby cały czas trzymać się unikalności kondycji ludzkiej, z której to doświadczenie wyrasta. Antropologia rości sobie pretensje, by poznać zarazem to, co indywidualne, jak i rodzaj ludzki w ogóle.

Nie myślę o tym jednak jako o kompromisie statycznym, jako o uśrednieniu i drodze środka. Myślę o tym raczej jako o sposobie zdobycia wglądu i wiedzy przez stałe zygzakowanie między przeciwległymi biegunami.

Prawda jest żywa i nie leży spokojnie w połowie drogi między czymś a czymś. Jedynie dokonując nieustannych wypadów w obie strony możemy ją odnaleźć, i choć zasadnicza tajemnica leży w zachowaniu proporcji, poszukiwania prowadzone z tym założeniem są z góry skazane na niepowodzenie.

Te słowa, napisał powieściopisarz E.M. Forster ${ }^{13}$, co skądinąd dobrze się składa, skoro mowa tu o reprezentacji. W tym fragmencie Forster rozważa, jak opisać „angielskie społeczeństwo" albo „,angielski charakter”, tak żeby zarazem oddać sprawiedliwość jego sprzecznościom, jak i jednostkom, z których się składa. Jak pisać w sposób całościowy, ale zarazem niedomknięty? Jest to problem, który jest bliski naszemu: w jaki sposób podjąć się obiektywnego opisu ludzkiej kondycji i różnych socjokulturowych milieux (a ostatecznie całego społeczeństwa globalnego), nie redukując przy tym niczego, nie pomijając ani w żaden inny sposób nie zaburzając obrazu szczegółu związanego $\mathrm{z}$ doświadczeniem indywidulanym, chwilowością interakcji i różnorodnych symbolik stojących za wspólnotowymi klasyfikacjami. Forster udziela odpowiedzi z porządku i strumienia narracji. Pisarz wyraża prawdę, zestawiając opisy różnych ludzi i różnych dziedzin wiedzy, umieszczając ich w swoim tekście w taki sposób, że między tymi różnicami nawiązują się relacje. Co istotne,

Group for Debates in Anthropological Theory (1989), Social Anthropology is a Generalizing Science or it is Nothing, ed. by T. Ingold, Department of Social Anthropology, University of Manchester, Manchester, egzemplarz powielony.

13 E.M. Forster Powrót do Howards End, przeł. E. Krasińska, Prószyński i S-ka, Warszawa 2009, S. 193. 
te powiązania nie przyjmują formy ujednolicenia, wykrycia wspólnego mianownika. Nie ma tu kompromisu, który zaciera realną różnicę. Poszczególni ludzie, relacje społeczne i światopoglądy nie zlewają się ze sobą. Ich odrębność i wewnętrzna spójność zostają uszanowane. Autor tymczasem podejmuje jednak interpretacyjno-imaginacyjną, metaforyczną podróż do każdego z tych światów i do tej właśnie podróży zaprasza czytelnika. Życie społeczne nie ma być przy tym ujęte poprzez zacieranie różnic ani przez trwałe zajęcie pozycji po jednej czy drugiej stronie, ani też przez próbę znalezienia drogi środka. Prawda o życiu społecznym jest taka, że jest ono „żywe” i zawsze w drodze od jednego do drugiego bieguna. Tę prawdę można znaleźć i opisać poprzez ruch pisarza między doświadczeniami różnych ludzi, między wglądami w różne interakcje i kosmologie ${ }^{14}$.

Forster dochodzi do wniosku, że:

Uogólnienia dobre są dla księży i naukowców, my wiemy aż nadto dobrze, jak zawodne są wszelkie ogólniki wobec tych, których kochamy; nie czeka ich wspólne niebo ani nawet jedna wspólna niepamięć. ${ }^{15}$

Można powiedzieć, że to ostatnie stwierdzenie Forstera jest należycie paradoksalne. Jego uogólnienie („zawodne są wszelkie ogólniki”) dotyczy konkretu, który nie poddaje się uogólnieniu. Wiedza subiektywna - wiedza indywidualnego podmiotu i wiedza o tymże podmiocie - nie redukuje do abstrakcji..., co już jest pewnym uogólnieniem i być może tym właśnie poznaniem, które pisarz ma oddać: uogólnieniem konkretności. Widzę w tym lekcję dla nauki antropologicznej. Opisywanie ludzkich prawd może być paradoksalne, przypominać chimerę. Ale potrzeba tego bieguna ludzkiej ogólności potrzeba go jako ontologii i jako etyki. Metodologicznie chodzi o to, żeby poruszać się między tym, co w ludzkim świecie jest złożoną unikalnością, a tym, co jest indywidualnym zróżnicowaniem. Należy poruszać się między tymi biegunami bez ustępstw, podtrzymując dialektyczne napięcie między nimi. Do prawdy dojdziemy przez ciągły ruch tej analizy. W ten sposób można osiągnąć obiektywność subiektywności.

Georg Simmel zaproponował termin „współobecne przeciwstawienie” (co-present dualism) jako nazwę dla tej opisowo-analitycznej łączliwości

\footnotetext{
14 N. Rapport "The Truth is Alive": Kierkegaard's Anthropology of Subjectivism, Dualism and Somatic Knowledge, "Anthropological Theory" 2002 No. 2 (2), s. 165-183. 
(connectivity) czy też cybernetyki, jaką postulował Forster. „Jeden z głębokich obiegów życia intelektualnego", pisze Simmel ${ }^{16}$, polega na tym, że „jeden element z góry zakłada drugi element, który z kolei zakłada ten pierwszy". Simmel przyznaje, że taka dialektyczna jedność jest w pewnym sensie tajemnicza, to „jeden z tych punktów, w których bycie i rozumienie pozwalają się empirycznie odczuć w ich mistycznej jedności". Niemniej ta dialektyka jest prawdziwa i fundamentalna. Ucieleśnia ona jedną z głębokich prawd o ludzkiej kondycji. Życie społeczne człowieka trzeba rozumieć jako $\mathrm{z}$ analitycznego punktu widzenia pełne takich konstytutywnych współobecnych przeciwstawień: „publiczne i prywatne”, „reguła i praktyka”, ,antagonizm i solidarność”, „wolność i ograniczenie”, ,inwencja i konwencja”, „bunt i podporządkowanie”, „forma i znaczenie”. To właśnie z napięcia i ze strumienia życia między nimi rodzi się doświadczenie społeczne, proces społeczny i struktura społeczna. Powiedziałbym, że tak samo jest z parami „to, co w ogóle ludzkie i to, co indywidualne”, oraz „ogólność i przypadek jednostkowy”. One również są podobnymi współobecnymi przeciwstawieniami i z napięcia między tymi właśnie biegunami wywodzą się fundamentalne aspekty ludzkiej kondycji i nasza możliwość ich zrozumienia. Nadzieja na zrozumienie ludzkiej kondycji to nadzieja na utrzymanie tej dialektyki „przy życiu”, zachowanie tej „współobecności” w naszych opisach i analizach. Wgląd nie bierze się ze skupienia się na jednym elemencie danego przeciwstawienia i pominięciu drugiego ani z zamknięcia opozycji w syntezie, ale właśnie z podtrzymywania napięcia przez nieustające, analityczne i opisowe wycieczki między nimi. 'Tylko łączyć' (E.M. Forster); dążymy do tego, by intelektualnie i przedstawieniowo zajmować się zarazem tym, co ogólne i tym, co partykularne.

\section{Epistemologia typu "możliwość kontra realizacja"}

Wcześniejsze debaty o naturze ludzkiej często grzęzły w podziałach procentowych: ile z naszego zachowania pochodzi z natury, a ile z socjalizacji? Jak starałem się pokazać, prawda jest bardziej płynna, a dochodzimy do niej przez stały opisowo-analityczny ruch między biegunami uniwersalności i partykularyzmu. To jest nie tyle podział, co przeciwstawienie. Co więcej, chcę teraz powiedzieć, że jest to przeciwstawienie różnych zjawisk ontologicznych: możliwości czy potencjału i realizacji. One nie reprezentują 
żadnego matematycznego rozkładu, żadnego „mniej” ani „więcej”, żadnego „albo albo”, lecz „zarazem”. Istoty ludzkie są jednakowe w swoich ogólnych możliwościach, wspólnych dla całego gatunku, i radykalnie odmienne od siebie w tym, w jaki sposób te możliwości są realizowane w życiu. W podejściu antropologicznym opisanie człowieka nie jest przypisaniem mu z góry jakiejś realizacji ludzkiej natury (w rodzaju „być człowiekiem to myśleć i czuć to, chcieć tego, mieć to"), ponieważ życiowa realizacja zawsze będzie konkretna i unikalna. Antropolodzy mogą mieć jednak nadzieję na rozpoznanie uniwersalnych ludzkich możliwości indywidualnej realizacji życia konkretnych ludzi. Te możliwości zawierają zarówno zdolności (capabilities), np. zdolność myślenia i czucia, chcenia i posiadania, działania i wyobrażania sobie, ale zawierają też ułomności (liabilities), takie jak podatność na chorobę, okrucieństwo, cierpienie i samotność.

Uważam, że różnica między możliwościami a realizacją jest analogiczna do koncepcji Sartre'a ${ }^{17}, \dot{z}$ e „egzystencja poprzedza esencję”. Człowiek przychodzi na świat bez tożsamości: „w chwili narodzin każde dziecko jest istotą ludzką"', w bardziej współczesnym sformułowaniu Marthy Nussbaum ${ }^{18}$. Noworodek ma pewne uwarunkowania i słabości, np. jeśli chodzi o zapewnienie mu pożywienia czy komfortu, ale ma też wspólne całemu naszemu gatunkowi zdolności stworzenia tożsamości i określonego środowiska. To, w jaki sposób zostaną one zrealizowane - to już rzecz indywidualnej praktyki i intencjonalności. Nie ma jednego ogólnego schematu realizacji ludzkich możliwości. Dlatego też w swej realizacji poszczególne żywoty jednostkowe są niepowtarzalne, i to niepowtarzalne w wielu różnych aspektach, zarówno pod względem cielesnym, jak i mentalnym, zarówno praktycznym, jak i wyobrażeniowym. W swoich przełomowych badaniach nad intencjonalnością (i wolą), Franz Brentano i Edmund Husserl podkreślają jej przechodni charakter: intencja (czy też chęć) zwraca się zawsze do czegoś konkretnego poza jaźnią; zawsze chodzi w niej o pewne vis-à-vis. Nie znaczy to jednak, że intencja wzięta jako możliwość jest nieodróżnialna od konkretnych aktów intencjonalnych. Natura i siła intencji nie są ograniczone przez sumę wszystkich odnotowanych przypadków, w jakich intencja się realizowała. Można argumentować, że intencja jako możliwość jest czymś innym niż to,

17 J.-P. Sartre Existentialism is a Humanism, w: Existentialism from Dostoevsky to Sartre, ed. by W. Kaufman, New Arena Library, New York 1975, s. 348.

18 M. Nussbaum Patriotism and Cosmopolitanism, w: Love of Country: Debating the limits of patriotism, ed. by J. Cohen, Beacon, Boston 1996, s. 142. 
czego ta intencja dotyczy. Poszczególne akty intencji czynią intencjonalność jako taką widoczną, ale nie są z nią tożsame. Intencjalność ma swoją własną naturę. Można stwierdzić, że człowiek jest stworzeniem dysponującym możliwością intencji, a ludzka nauka może postawić sobie zadanie prześledzenia poszczególnych aktów tak, by stworzyć dokładniejszy (choć niekoniecznie systematyczny) portret ogólnej natury, która to wszystko warunkuje.

Ale jak możemy antropologicznie ująć możliwości łączące wszystkich ludzi? Proponuję, byśmy zaczęli od tego, że w życiu każdego zwierzęcia jest pewna wrodzona otwartość. Fakt, że zwierzę posiada system nerwowy, oznacza, że ten oto indywidualny organizm jest przecięciem dwustronnego ruchu informacji i energii, które ciągle i w obie strony przekraczają powierzchnię skóry. Jak tłumaczy psycholog zwierzęcy Scott Turner ${ }^{19}$, organizmu nie wyróżnia sam fakt istnienia jego granicy, tj. skóry, ale to, co ta granica robi - może ona aktywnie, „adaptacyjnie” kontrolować przepływ materii i energii w taki sposób, że wewnętrzny stan organizmu jest regulowany w odpowiedzi na zmieniające się warunki zewnętrzne. Co więcej, regulacja przepływów energii i materii przez tę granicę konstytuuje pewne „uporządkowanie” w naturze, takie, że tworzące je organizmy mogą być opisane jako „architekci i inżynierowie swoich środowisk"20. Być zwierzęciem ludzkim oznacza mieć możliwość wchodzenia w interakcję ze światem w szczególny sposób - sterując tym ruchem informacji i energii przechodzącym przez powierzchnię skóry z niezwykłą subtelnością, złożonością i elastycznością. Poza zwierzęcą koniecznością bycia-w-świecie na określone sposoby jest jeszcze ludzka zdolność (a zarazem ludzka ułomność) polegająca na tworzeniu zróżnicowanych uważności oraz na bolesnym odczuwaniu zróżnicowanych ograniczeń. Ludzie mają unikalną możliwość stawania się - mogą ją w sposób unikalny wykorzystać, a mogą też w unikalny sposób ją marnować.

Jeśli więc chodzi o ludzką naturę, możemy opisać otwartość jako potenciał (capacity) przekroczenia własnej tożsamości, czasu i miejsca, przetłumaczenia przestrzennego sensu konkretnych środowisk na działanie technologiczne, jako możliwość rozumienia norm i tworzenia kultury określonych miejsc, jako potencjał zaspokajania osobistych pragnień, realizowania wartości, które się sobie obrało i budowania swojej samooceny, także jako możliwość komunikacji, intuicji i dokonania interpretacyjnego wglądu w przekonania

19 J.S. Turner The Extended Organism, Harvard University Press Cambridge 2000.

20 Tamże; por. N. Rapport I am Dynamite: An Alternative Anthropology of Power, Routledge, London 2003, s. 220-226. 
i zamiary innych, jako potencjał rozumienia i doceniania wzajemności i wspólności, symetrii, klarowności i sprawności, jako potencjał żywienia nadziei i dokonywania projekcji, i tak dalej. Rzekłbym, że ludzka otwartość przejawia się w wychodzeniu poza. Antropologowie najchętniej rejestrują to, co ludzkie, w powszechnej skłonności do ironicznego odnoszenia się do ograniczeń tożsamości: do wyjścia poza teraźniejsze okoliczności bycia, poza ich uwarunkowania i pozorne ograniczenia, poza kategorialne aspekty klasyfikacji symbolicznych - granice między rzeczami a relacjami - które ludzie tak biegle wynajdują i których tak zapalczywie bronią.

Jeśli nasza natura jest zbiorem możliwości działania i zaspokojenia, fundamentalną otwartością na świat i możliwością wyjścia poza to, czym on jest teraz, to, jak powiedział poeta Philip Larkin, „w tym, jak nam się żyje, odbija się nasza natura"21. O ile ludzka praktyka obejmuje wykraczanie w sposób istotowo zdecydowany poza teraźniejszość za pomocą celowego projektowania porządku (struktury, zwyczaju, regularności) albo i nieporządku (antystruktury, spontaniczności, przypadkowości) w przyszłość, o tyle ten potencjał może różnorodnie znajdować wyraz w różnych momentach. To, jak kreujemy warunki naszego życia, jest związane z konkretnym wykorzystaniem naszych możliwości. Zróżnicowanie i zmienność tych okoliczności, ich konkretność, idiosynkrazja i indywidualność wydobywają więc naszą ogólnogatunkową otwartość, ale również to, w jaki sposób nasza uważność na świat zawiera i przejawia osobisty namysł $\mathrm{i}$ intencjonalność. „W tym, jak nam się żyje, odbija się nasza natura", a to, jak nam się żyje, jest ucieleśnieniem różnicy - żadne indywidualne ludzkie życie nie jest identyczne z innym. Nasza uniwersalna ludzka natura przejawia się w niekończącym się, twórczym bogactwie indywidualności.

Nasze życie i osobiste projekty życiowe, nasze kultury i społeczności są naszymi „dziełami sztuki”. Sformułowanie pochodzi od Nietzschego ${ }^{22}$, jest częścią metafizyki, która stawiała sobie za cel podkreślenie, że to, co może się wydarzyć jako element poszczególnego życia, nie daje się opisać, z góry określić ani przewidzieć nawet na podstawie leżących u jego podłoża uniwersalnych, naturalnych możliwości. Dla Nietzschego był Człowiek i był Nadczłowiek, a relacja między nimi wiązała się z tym, co konkretny człowiek

21 P. Larkin 44 wiersze, przeł. S. Barańczak, Arka, Kraków 1991, S. 51.

22 F. Nietzsche Zmierzch bożyszcz czyli Jak filozofuje się młotem, przeł. S. Wyrzykowski, vis-à-vis etiuda, Kraków 2015, s. 343. Por. F. Nietzsche Wola mocy, przeł. K. Drzewiecki, S. Frycz, vis-à-vis etiuda, Kraków 1967. 
robił ze swoim naturalnym dziedzictwem. Nadczłowiekiem był każdy konkretny Człowiek realizujący maksimum swojego samostwórczego potencjału. Wydaje mi się, że antropologia ma szczególnie dogodną pozycję, żeby zdać sprawę z tego, że ludzkie życie jest samostworzone. Jako etnografowie stajemy twarzą w twarz - dosłownie - z niekończącą się feerią ontogenetycznej różnorodności. Jesteśmy najlepszymi świadkami tego, jak ludzie, zarówno jednostkowo, jak i kolektywnie, realizują swoje ogólnogatunkowe możliwości na kunsztowne, indywidualne sposoby, tworząc niepowtarzalne światy życia: światopoglądy, relacje międzyludzkie, organizacje społeczne, struktury społeczne, praktyki i tradycje kulturowe. Badania etnograficzne dają światu najbardziej subtelne sprawozdanie z praktycznej, nieustająco dialektycznej relacji między możliwością a intencjonalnością. Wrodzona człowiekowi otwartość - nasz potencjał przekraczania i wychodzenia poza - ujawnia się w konkretnym życiu konkretnych ludzi. Antropologia mogłaby uczynić zadość tej fenomenologii.

\section{Studium przypadku}

Wciąż pamiętam wrażenie, jakie wywarło na mnie pierwszy raz usłyszane podsumowanie Benedicka pod koniec Wiele hałasu o nic: „Człowiek chwiejne stworzenie i na tym koniec"23. (Przyznaję, że to było w filmowej adaptacji dzieła Szekspira, w filmie grali Kenneth Branagh i Emma Thompson). To, co Szekspir zawarł w tych kilku słowach, napisanych w 1598 lub 1599 roku, słowach w których postać Benedicka mówi o własnych sprzecznościach - przyznając się do nich i godząc się z nimi - dobrze współgrało z moim doświadczeniem. Był to w istocie rdzeń tezy, którą ciężko wypracowałem w czasie moich antropologicznych badań w terenie, w środowisku wiejskim w północnej Anglii, w miejscu, które, dla zanonimizowania, nazwałem „Wanet”. Próbując zrozumieć partykularność zachowań przejawianych przez różne Doris i Sidów, przez różnych Fredów i Florence, doszedłem do wniosku, że jednostka ludzka jest niejako zbiornikiem różnorodnych sprzecznych tożsamości ${ }^{24}$.Ta różnorodność wynika ze stałego wysiłku twórczego, w którym powstaje zarówno tożsamość, jak i inność i sam świat, a którego to wysiłku

23 W. Szekspir Dzieła dramatyczne, t. 1 Komedie I, PIW, Warszawa 1973: Wiele hałasu o nic, Akt V, scena iv, wers 109, przeł. L. Ulrich.

24 N. Rapport Diverse World-Views in an English Village, Edinburgh University Press, Edinburgh 1993. 
jednostka nigdy nie porzuca. Sprzeczność jest tutaj powszechną formą poznawczej i praktycznej otwartości i nadmiaru. Jest świadomą grą, a zarazem zaprzeczeniem tożsamości i relacji, zwielokrotnieniem klasyfikacji symbolicznych w momencie, w którym każda z nich została uznana za prawdziwą. Co więcej, kiedy w Wanet dochodziło do interakcji między poszczególnymi osobami (mam tu na myśli zarówno wymianę werbalną i behawioralną, jak i wymianę w znaczeniu najbardziej przyziemnym, w zwyczajnych relacjach i w ojczystym języku), wówczas różnorodność dostępnych obrazów świata wzrastała wykładniczo. Doszedłem do wniosku, że życie społeczne jest sceną na której więcej jest zwielokrotnienia i sprzeczności niż homogeniczności, więcej niespójności, losowości i bezcelowości niż systematyczności. U Szekspira znalazłem to, co uznałem za miarodajny wgląd w sprawy ludzkie: że życia społecznego nie da się ująć w schludnych, mechanicznych modelach i uporządkowanych systemach, w tekstach normatywnych czy jakichkolwiek konwencjonalnych uzusach takich terminów objaśniających jak „struktura” i „funkcja”, „synteza” i „konsensus”, ,hegemonia” i „spójność”. Życie społeczne jest złożone i sprzeczne, chaotyczne, jest polimorficzną farsą, mozolnym, przypadkowym brnięciem² ${ }^{25}$ Najwyraźniej Szekspir już 400 lat temu przewidział wyniki moich badań etnograficznych w Anglii.

Jakieś dwieście lat po Wiele hałasu o nic Szekspira, w roku 1791, James Boswell opublikował Żywot doktora Samuela Johnsona. W dziele tym jest sławny fragment opisujący zdarzenie, do jakiego doszło między nimi w 1763 roku:

Po wyjściu z kościoła staliśmy jeszcze jakiś czas, rozmawiając o genialnej sofistyce biskupa Berkeleya, który dowodził, że materia nie istnieje a wszystko w świecie ma charakter idealny. Zauważyłem, że choć jesteśmy przekonani, że jego doktryna jest nieprawdziwa, nie sposób ją obalić. Nigdy nie zapomnę, jak ochoczo Johnson odpowiedział, z całej siły kopiąc stopą w spory kamień, od którego aż się odbił. „Tym samym ją obaliłem". 26

25 N. Rapport The "Contrarieties" of Israel: An essay on the cognitive importance and the creative promise of both/and, "Journal of the Royal Anthropological Institute" 1997 No. 3 (4), s. 653-672; N. Rapport Random Mind: Towards an Appreciation of Openness in Individual, Society and Anthropology , "The Australian Journal of Anthropology" 2001 No. 12 (2), s. 190-220.

26 J. Boswell Life of Johnson (Book I), Oxford University Press, Oxford 1935, s. 471. Polskie tłumaczenie Żywota Samuela Johnsona nie zawiera tego fragmentu, por. J. Boswell Żywot doktora Samuela Johnsona, przeł. TJ. Dehnel, s. 48, powyższy cytat w tłumaczeniu naszym [przyp. tłum.]. 
George Berkeley, który zmarł w roku 1753, był sławny jako twórca doktryny idealizmu subiektywnego, według której możemy być pewni, że istnieje umysł i treści umysłu, ale nie możemy być pewni, że przedmioty fizyczne istnieją niezależnie od tego, że są postrzegane. Stąd też bierze się Berkeleyowski szlagwort, że „być to być postrzeganym” (esse est percipi). Dr Johnson chciał zademonstrować, że realny świat istnieje niezależnie od naszych jego obrazów: kopnięcie kamienia było aktem poznania realności świata przez fizyczną interakcję, a nie przez aprioryczną czy mentalną metafizykę. To kopnięcie było praktyką rozumianą jako przeciwieństwo „czystej” racjonalności. To, co w ten sposób odkrywa, to materialność, od której się odbija. Johnson nie ma możliwości, by jego kopnięcie przeszło przez kamień na wylot, Boswell też to widzi. Kamień ma masę i inercję, która może wywrzeć wpływ na świadomość Johnsona i Boswella, jeżeli będą próbowali kopnąć przez kamień. Kamień nie może narzucić żadnej konkretnej percepcji czy interpretacji (nie da się stwierdzić, jakie były osobiste doznania czy odczucia Johnsona czy Boswella), ale obaj muszą przyjąć do wiadomości „inność" i obiektywność kamienia.

Opowieść Boswella i scena kopania w kamień wróciła do mnie w czasie nie tak dawnych badań terenowych, kiedy pracowałem jako personel pomocniczy w szpitalu we wschodniej Szkocji. Pracował ze mną niejaki Roger Weir, który stał się moim regularnym rozmówcą. Zaczęliśmy pracę tego samego dnia i przeszliśmy przez te same procedury wprowadzające. Roger był około 20 lat młodszy ode mnie (był ledwo po dwudziestce), ale swoje wdrażanie się w instytucję szpitala i jej hierarchię zestawiałem z tym, jak to wyglądało u niego: często spotykaliśmy się w porze lunchu, wspólnie jedząc kanapki w cichym kącie stołówki i porównując doświadczenia z bieżącego dnia czy tygodnia, wymieniając się historiami sukcesów i porażek.

Niedługo po tym, jak się poznaliśmy, Roger zdradził mi, że urodził się jako wcześniak. W związku z tym miał pewne specyficzne warunki fizyczne. Jego ścięgna w nogach były dosyć krótkie i chodził przez to w dosyć niezwykły sposób, trochę jakby jechał na nartach biegowych, ślizgając się po podłodze bez podnoszenia stóp, na zgiętych kolanach i z rozstawionymi na zewnątrz piętami. Żeby te ścięgna rozciągnąć, zaczął uprawiać karate i to stało się ważną częścią jego życia: chodził na karate trzy razy w tygodniu przez ostatnich osiem lat. Została mu jednak słaba koordynacja i dysleksja (co jest już inną sprawą). Roger opowiedział mi też o swojej innej miłości, czyli o muzyce, a konkretnie o Black Sabbath i Ozzym Osbournie, a więc ucieleśnieniu „Heavy Metalu”. Nogi były dla niego ograniczeniem w karate, ale 
w muzyce ograniczeń nie było: mógł słuchać Black Sabbath do woli, mógł pisać własne piosenki i śpiewać w swoim zespole. Roger dzielnie przekonywał mnie, że w jego życiu nie było ograniczeń w ogóle, więc: „Dajemy, Nigel, dajemy".

Podczas gdy ja pracowałem dalej przy obsłudze głównego wejścia do Constance Hospital, Roger został potem przeniesiony na blok operacyjny - co szybko znienawidził. Było to nudne, brudne zajęcie, a ludzie tam pracujący byli urzędowymi automatami i nie znali znaczenia słowa „zabawa”. Skarżył mi się, że musiał (bez żadnego przygotowania) sprzątać po zabiegach medycznych: zakrwawione podłogi, zakrwawione chodaki i fartuchy, fragmenty ciał... Czuł się jakby zatrudnił się jako służący. I jeszcze obawiał się, że czymś się zarazi. Roger zdecydował, że musi zacząć mówić przełożonym wprost, co myśli. (Praca w szpitalu nie była przecież główną rzeczą w jego życiu - gdzież jej było do rzeczy naprawdę ważnych, takich jak muzyka albo zabawa!)

Roger wielokrotnie mówił mi o dwóch wyjazdach, które planował. Pierwszy to coroczny Black Sabbathowy festiwal "Ozzfest” w Milton Keynes pod Londynem, a drugi to tour z karate po Japonii, gdzie mógłby jeszcze lepiej przyswoić zwyczaje, duchowość i doskonałą dżentelmeńskość japońskich mistrzów. Tymczasem jednak Roger trwał w Constance i był zdecydowany zadbać o swoje interesy. W ramach podzielenia się ze mną swoją wizją własnego charakteru i życiowego projektu powiedział mi, że jest ,szalonym dzieckiem o złotym sercu". Wśród personelu był jednak uznawany raczej za głupka czy wręcz za kogoś upośledzonego na umyśle. Czułem jednak, że do bycia nierozumianym i traktowanym z góry Roger jest po prostu przyzwyczajony. Mówił mi, że tak długo, jak ma szansę współuczestniczyć i należeć, nie przejmuje się tym, że jest traktowany prześmiewczo.

Ze znajomości z Rogerem najbardziej zapamiętałem, jak idziemy wspólnie długim, szerokim i ogólnodostępnym korytarzem w szpitalu, każdy zmierza do swojej pracy. Ja jestem ubrany w moją urzędową żółtą koszulkę polo z identyfikatorem „N. Rapport, personel pomocniczy” przypiętym do piersi. Roger ma na sobie zielone ubrania, jakie nosi się na bloku operacyjnym. Idziemy ramię w ramię, Roger swoim quasi-narciarskim krokiem, a ja ze swoim płaskostopiem i kołysząc ramionami. Tak sobie idziemy, a Roger, ku zdziwieniu tych, którzy nas mijają, głośno udaje, że gra kawałki Black Sabbath na gitarze. Albo demonstruje ciosy karate, pokazując mi i wszystkim innym, swoją ciężko wypracowaną formę fizyczną. Pokazuje, że ma sprawne nogi, że kopnięciem sięgnie wysoko i że może być potencjalnie niebezpieczny. 
Drzwi, które mijamy, otwiera kopniakiem, zrywa kartki przypięte do tablic ogłoszeniowych i obija się o najwyraźniej niewzruszone ściany, co nie robi na nim wrażenia.

Czytałem opowieść Jamesa Boswella o doktorze Johnsonie i odczytywałem ekspresywną cielesność Rogera Weira i rozumiem, jak ludzki potencjał wymierzenia światu kopniaka może być użyty w działaniu, zrealizowany, żeby powiedzieć i zrobić rzeczy bardzo konkretne. Wydaje mi się, że w tym moim zestawieniu Samuela Johnsona i Rogera Weira, w zestawieniu, w którym moja myśl zygzakuje między doświadczeniem ich obydwu, istotne jest, że to, co ogólnoludzkie i to, co indywidualne, staje się dla mnie biegunami analitycznego myślenia. Roger nie jest w swojej istocie „Szkotem”, ,pracownikiem szpitala”, „białym” czy „mężczyzną”, a dr Johnson nie jest esencjalnie "Anglikiem”, ,zdroworozsądkowym filozofem” czy „mistrzem pióra z XVIII wieku". Nie. Ludzka egzystencja poprzedza esencję. Przyporządkowania, zarówno te konkretne, jak i w ogóle jakiekolwiek przyporządkowanie związane z kategoriami z tym, co wspólne w klasyfikacji kulturowej i co sugeruje możliwość sprofilowania świadomości i tożsamości - to jest wszystko wtórne, to jest epifenomen. Takie przyporządkowania niczego nie wyjaśniają. Są retorycznymi czy też dyskursywnymi aktami nazywania, definiowania i zamykania w definicjach. Ale jedyna definicja, którą czuję, że mam prawo sformułować jako antropolog, to ta, która dotyczy natury ludzkiej. Roger Weir i doktor Johnson wymierzają kopniaka światu, który ich otacza, i to jest ta ludzka cecha, która jest im wspólna. Żaden z nich nie potrafi kopnąć przez kamień lub mur na wylot - i to jest ludzkie ograniczenie, które jest im wspólne. Natomiast, co nie jest im wspólne, to sposoby, na jakie mają zamiar i determinację wyrazić czy zrealizować swoje możliwości w swoim jednostkowym życiu. Zygzakując między opowieściami o doktorze Johnsonie i o Rogerze Weirze, zestawiając je tak, jak to tutaj zrobiłem, sprawiamy, że ludzki kontekst „staje się ciałem”. Robiąc to, niejako wyjmuję obu z "przypadkowości” ich urodzenia i z "tekstów” ich kultury, tak by w pełni ich poznać jako konkretne i odrębne istoty ludzkie: jak to jest zamieszkiwać ich ciała? Wydobywam ich również z przypadkowości i przypadłościowości kontekstów historycznych, społecznych i kulturowych, tak by lepiej poznać to, co ludzkie jako rzeczywistość ontologiczną. Jest to kontekst, który jest realny w sensie, w którym symboliczne przyporządkowania, klasy i dyskursy "personelu pomocniczego w szpitalu”, , angielskiego dżentelmena” itd. prawdziwe nie są. Mogę wreszcie dojść do wydania sądu moralnego, czy Roger Weir i doktor Johnson byli czy nie byli w stanie zrealizować swoje 
możliwości zgodnie z ich własną intencją: na ile otoczenie utrudniało im to bądź ułatwiało.

\section{Kontekst globalny}

„To, że przypadkiem dana osoba gdzieś się urodziła, to właśnie tylko tyle: przypadek”, pisze Martha Nussbaum ${ }^{27}$; „każdy człowiek mógł się urodzić w którymkolwiek z narodów". Powiedziałbym nawet, że proces globalizacji wydobywa na pierwszy plan unikalność naszego człowieczeństwa i jednostkowość człowieka. Sprawia też, że wspólnotowa retoryka historycznie określonych i ograniczonych, zbiorowych tożsamości jawi się wyraźnie jako ideologia, kulturowa fikcja. Innymi słowy, koncepcja, że indywidualna tożsamość jest konstytuowana i na stałe uwiązana przez określone środowisko kulturowe, określone przekonania i praktyki, określone historie, obyczaje i dyskursy - a także pokrewne twierdzenie, że jednostki, które odrzucą takie kolektywnie wyznaczone światy społeczne, znajdują się w rezultacie w sytuacji ontologicznego rozpadu, bez zakotwiczenia społecznego i bezpieczeństwa poznawczego - muszą zostać odrzucone w świetle coraz liczniejszych świadectw w postaci ludzi, dla których domem jest ruch i zmiana ${ }^{28}$. Jednostka przemierzająca globalne przestrzenie staje się, jak to określił Marc Augéé niepodważalnym „konkretem antropologicznym”. Tradycyjne rozumienie społeczeństw jako tożsamych z kulturami stanowiącymi odrębne całości miało według Augé zawsze charakter ideologiczny, były to fikcje wytwarzane zarówno przez antropologów, jak i ludy, które badali. Sądzi on jednak ${ }^{\mathbf{3 0}}$, że prawdopodobnie nikt nigdy nie był nieświadomy tej iluzorycznej natury relatywistycznej retoryki wspólnotowej. Wizja zamkniętego, samowystarczalnego świata kultury i społeczeństwa zawsze była tylko poręczną wizją, prowizorycznym mitem, nawet dla tych, którzy się z nim identyfikowali; był to częściowy fantazmat tyleż rdzennej społeczności, co teorii Maussa. Doświadczenie globalizmu pozwala nam jednak wyzbyć się takich fantazmatów. Ta fikcja czy też mit zasadza się na szczególnej organizacji przestrzeni, którą

27 M. Nussbaum Patriotism and Cosmopolitanism, s. 7.

28 N. Rapport, A. Dawson Migrants of Identity: Perceptions of Home in a World of Movement, Berg, Oxford 1998.

29 M. Augé Nie-miejsca. Wprowadzenie do antropologii hipernowoczesności, przeł. R. Chymkowski, PWN, Warszawa 2012, s. 10. 
globalizacja przezwycięża i na którą pozwala spojrzeć z dystansu. Globalny kontekst ludzkiej praktyki sprawia, że nie sposób już posługiwać się ontologicznymi, całościującymi pojęciami kultury, społeczności zakorzenionych w lokalności i stereotypowych jednostek ${ }^{31}$.

Nie oznacza to, że prawda o naszej naturze ludzkiej - naszej uniwersalnej tożsamości i uniwersalnej, jednostkowej odmienności - obecnie dominuje. Przeciwnie, jesteśmy świadkami żywiołowego, wręcz gwałtownego jej wypierania w obrębie retoryki zamknięcia i wspólnotowości wykluczającej, często skrajnie fundamentalistycznej i totalitarnej ${ }^{32}$. Ludzie powszechnie postrzegają się jako przynależni do jakiegoś ludu, nie jako osoby, jak to ujmuje John Gray ${ }^{33}$.Żyjemy w epoce polityki tożsamości, kiedy ludzie nie definiują ani siebie, ani innych poprzez ich człowieczeństwo i indywidualność, lecz istnienia będące częścią zbiorowości, konstytuowane przez wspólnotowe historie, tradycje i afiliacje. „Kultury to nie opcje”, twierdzi Bhikhu Parekh $^{34}$, ważny głos brytyjskiego lobby multikulturalizmu. Domagając się "obywatelstwa multikulturowego" w Kanadzie, Will Kymlicka ${ }^{35}$ tłumaczy, że „kulturę" należy uznać za synonim „narodu” bądź „ludu”., Kultura” to według niego międzypokoleniowa wspólnota, kompletna instytucjonalnie, zajmująca określone terytorium, połączona odrębną historią i językiem. W książce Strange Multiplicity ${ }^{36}$ James Tully jest jeszcze bardziej dosadny: pisze, że dla istot ludzkich naturalne jest odnajdywanie i rozpoznawanie siebie w zwartych grupach, rozłącznych i wewnętrznie spójnych, a różne grupy kulturowe porównać można do różnych gatunków zwierząt. Kultury wyznaczają zrozumiałe same przez się, quasi-biologiczne zbiorowości, podtrzymujące tradycje, które są dopasowane w sposób szczególny do ich członków, którzy są najszczęśliwsi, kiedy pozostają wierni własnej tradycji kulturowej i jej naturalnemu rozwojowi.

V. Amit, N. Rapport Community, Cosmopolitanism and the Problem of Human Commonality, Pluto, London 2012.

2 V. Amit, N. Rapport The Trouble with Community:Anthropological Reflections on Movement, Identity and Collectivity, Pluto, London 2002.

3 J. Gray Against the new liberalism: Rawls, Dworkin and the emptying of political life, "Times Literary Supplement" 3rd July 1992, s. 14.

B. Parekh Cultural Diversity and Liberal Democracy, w: Democracy, Difference and Social Justice, ed. by G. Mahajan, Oxford University Press, Delhi 1998, s. 206, 212.

W. Kymlicka Multicultural Citizenship, Oxford University Press, Oxford 1995, s. 19.

J. Tully Strange Multiplicity, Cambridge University Press, Cambridge 1995. 
Krótko mówiąc, multikulturalizm z radością oddaje się na nowo polemikom i retoryce antyoświeceniowej, kultywując pojęcia, z których byliby zadowoleni Heder i de Maistre, pojęcia, które były charakterystyczne dla przedoświeceniowego ancien régime'u, „społeczeństwa stanowego”. Tam mieliśmy do czynienia z ostrymi granicami, fundamentalnymi i hierarchicznymi różnicami między jednostkami jako przedstawicielami warstw, klas, płci, religii, grup etnicznych, narodów i ras - a więc pojęć, które XX-wieczne totalitaryzmy wykorzystywały, uzasadniając np. nazistowską politykę eugeniczną i ludobójczą. Twierdzenie, że „kultury to nie opcje”37 jest fałszywe. Można powiedzieć, że etnografia podważa każdą z wymienionych wyżej, rzekomo "naturalnych" cech grup o charakterze kulturowym. Kultury nie mają ostro wytyczonych granic, nie są rozłączne ani wewnętrznie spójne, nie stanowią ostoi powszechnie uznawanych tradycji, które rozwijały się w sposób naturalny, i są w sposób szczególny dopasowane do potrzeb członków danej kultury, zapewniając im szczęście. Tradycja kulturowa jest zawsze kwestią interpretacji i przedmiotem sporu, przynależność kulturowa to zawsze akt negocjacji i kontestacji, a praktyka kulturowa podlega zawsze konkretnej aplikacji, realizującej takie a nie inne interesy. Zbiorowości kulturowe zawsze istnieją w pewnym polu: dana kultura jest zawsze stwierdzeniem agonistycznym, rywalizacyjnym i kontrastującym z innymi kulturami. Podsumowując, „kultura” to proces i jedynie celowe programy fundamentalizmu kulturowego dążą do chwilowego unieruchomienia, dookreślenia i ograniczenia jego płynności, opowiadając się za skrystalizowaniem jakiegoś zbioru „tradycyjnych" stałych.

Charakteryzowałem tu naturę ludzką jako otwartą. „W tym, jak nam się żyje, odbija się nasza natura", jak Philip Larkin opisywał istotowo ludzką zdolność do tworzenia światów życia dookoła nas z najwyższą inwencją. Co więcej, ta otwartość jest indywidualna, ale też ludzka w ogóle, ontogenetyczna i filogenetyczna zarazem. Nie ma jasno określonego związku między możliwością i jej realizacją, tak jak nie ma z góry danego związku między kondycją i możliwościami - nie ma koniecznego, z góry określonego sposobu, jak istoty ludzkie mają wcielać w życie odziedziczone w ramach gatunku możliwości. Możliwość i jej realizacja są ontologicznie odrębne. W swoim działaniu i realizacji natura ludzka jest z natury swej jednostkowa. Owszem, istnieją uniwersalne ograniczenia - żadne ludzkie ciało nie ma możliwości latać ani przeżyć bez wody, wniknąć w cudzy umysł, przeżyć śmierć itd., ale 
w ogromnym stopniu to, co jednostka robi z danymi jej możliwościami, jest sprawą woli i praktyki.

Slogan multikulturalizmu (przejęty od Parekha), głoszący, że „kultury to nie opcje", jest nie tylko fałszywym twierdzeniem, jest też zgubny. Jeżeli egzystencja poprzedza esencję, jeżeli związek między ludzkimi możliwościami i ich indywidualnymi realizacjami jest nieokreślony, to rzec można, że wynika z tego pewne stanowisko moralne, skądinąd o antycznym rodowodzie (znane już z etyki Arystotelesa, jeśli nie dłużej). Moralność oddająca sprawiedliwość naszej naturalnej zdolności do określania substancji naszego życia indywidualnie musiałaby zakładać, że słusznie i na miejscu jest dać jednostkom przestrzeń do realizacji tej zdolności, do realizowania się tak, aby treść naszych jednostkowych żywotów była w możliwie dużym stopniu zależna nie tylko od naszych indywidualnych działań, ale też indywidualnych pragnień, wyboru i satysfakcji. Nie ma innej narzuconej przez moralność drogi realizacji ludzkich możliwości poza tą, na którą jednostka może sama dobrowolnie wkroczyć. Stworzenie antropologicznego rozumienia natury ludzkiej, łączącego elementy ontologiczne i moralne jest zadaniem ważnym i palącym.

Obok otwartości globalizacji, jednostek wyobrażających sobie swoje życiowe projekty w skali globalnej, należy przestrzegać przed zamknięciem kulturowego fundamentalizmu. Brian Barry ${ }^{38}$, w swojej, jak to określił, egalitarnej krytyce multikulturalizmu, pisze wręcz o nowych „wiekach ciemnych", które mogą zapoczątkować fundamentalistyczne i faszystowskie dyskursy polityki tożsamości. Globalizacja, jak ją opisuje Roland Robertson ${ }^{39}$, to coś, czego powinniśmy się spodziewać w postaci dialektycznego procesu: prowincjonalizm obok miejskości, irracjonalizm obok racjonalności, dyskryminacja i wykluczenie obok ludzkiej inkluzywności, stereotypy obok aktów odrzucania tradycyjnych kategorii esencjonalnych różnic. To w tym kontekście, w którym dyskursy zamknięcia będą istniały w dialektyce z praktykami otwartości, twierdzę, że antropologia natury ludzkiej to perspektywa silna i potrzebna. Lokujemy antropologię w centrum zaangażowania społecznego i politycznego, prawnego i konstytucyjnego i dajemy jej kosmopolityczną misję „rozpoznania człowieczeństwa wszędzie tam, gdzie się ono pojawia i zapewnienia jego podstawowym składnikom, rozumowi i potencjałowi

38 B. Barry Culture and Equality: An Egalitarian Critique of Multiculturalism, Polity, Cambridge 2001, S. 32.

39 R. Robertson Mapping the Global Condition: Globalization as the Central Concept, "Theory, Culture and Society" 1990 No. 7 (2/3), s. 15-30. 
moralnemu, naszej lojalności i szacunku"40 . Dzisiaj antropolog uważa, że człowiekiem jest się nie o tyle, o ile zamieszkuje się różne światy kultury, ale ponad i przeciwko takiej symbolice i retoryce. Przywrócenie naturze ludzkiej miejsca w samym centrum rozmyślań antropologicznych oznacza spojrzenie ponad kulturę i postawienie jej tam, gdzie jej miejsce. W ten sposób podejmuje się zobowiązanie wobec człowieka, wobec Każdego.

Przełożyli Olga Kaczmarek i Piotr Stankiewicz

\section{Abstract}

\section{Nigel Rapport}

ST. ANDREWS UNIVERSITY

Human Nature: The Premise and Promise of Anthropology

The question of human nature - what it is to be human - provides a prime site for 'anthropology in the world': a means to engage with debates beyond the academy and to show anthropology's special contribution. It also provides a means to anchor a discipline whose'writing of the human' encompasses the ethical and aesthetic as well as the scientific, the individually particular as well as the universally general, the personal alongside the social, cultural, historical, practical and biological.

\section{Keywords}

human nature, anthropology, human potential, realizing human potential, human uniqueness, zigzagging

40 M. Nussbaum Patriotism and Cosmopolitanism, s. 7. 